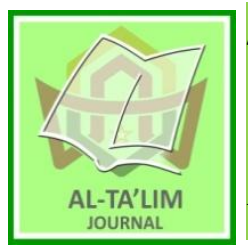

AL-TA'LIM JOURNAL, 25 (1), 2018, (87-96)

(Print ISSN 1410-7546 Online ISSN 2355-7893)

Available online at http://journal.tarbiyahiainib.ac.id/index.php/attalim

\title{
Mathematics Learning Devices Development based on Realistic Mathematics Education on Probability
}

Received: $21^{\text {th }}$ January 2018; Revised:20 ${ }^{\text {th }}$ February 2018; Accepted: $28^{\text {th }}$ February 2018

Permalink/DOI: http://dx.doi.org/10.15548/jt.v25i1.377

\section{Nana Sepriyanti *) \\ Universitas Islam Negeri Imam Bonjol \\ Padang, Indonesia. \\ E-Mail: munzilatululya@yahoo.com}

\section{Evi Mega Putri}

Universitas Islam Negeri Imam Bonjol

Padang, Indonesia.

E-Mail: evi1999@gmail.com

*) Corresponding Author

\begin{abstract}
The purpose of this research is to develop mathematics learning devices in the form of Lesson Plan (RPP) and Student Assignment (LKPD) based Realistic Mathematics Education(RME) on probability materials in line with curriculum 2013. In addition, this research aims to describe the quality of developed learning devices in both validity and practicality aspects. This is a development research with 4D model including define, design, develop and disseminate. The researcher modified the development model by simplified the model through limit the research up to develop stage by considering the time and the cost. The define stage consists of: a) curriculum analysis; b) student analysis; and c) concept analysis. The design stage consists of: a) Lesson Plan design; b) Student Assignment design; c) instrument design and validation on assessment instrument of learning devices. Meanwhile, the develop stage consists of: a) the validation of learning devices by the expert and mathematics teacher; b) testing; and c) the questionnaire of both teacher and students responses. This research produces mathematics learning devices in the form of Lesson Plan and Student Assignment basedRealistic Mathematics Education (RME) on Probability materials class X. The research findings shows that according to expert and mathematics teacher assessment, the developed learning devices are valid with 3.25 on average for lesson plan and 3.48 on average for student assignment. The result of the teacher response on the questionnaire shows that student response and interview display that mathematics learning devices in the form of lesson plan and student assignment are practical to be used on mathematics learning particularly on probability materials with 3.50 on average for Lesson Plan and 3.30 on average for Student Assignment.
\end{abstract}

Keywords: Realistic Mathematics Education (RME), mathematics learning devices, probability

How to cite: Sepriyanti, N., \& Putri, E. (2018). Mathematics learning devices development based on realistic mathematics education on probability. Al-Ta Lim Journal, 25(1). doi:http://dx.doi.org/10.15548/jt.v25i1.377

\section{INTRODUCTION}

Mathematics is one of the compulsory subjects to be learned in every level of education in Indonesia. However, today mathematics is not merely viewed as a compulsory subject at school but it is a subject which acts as a basic towards varied disciplines and that is absolutely important in facing today world (Council \& Committee, 2001; Mathematics, 2000). 
One of the topics studied in Mathematics high school is the Probability. The ability of students to solve the problem of probability is a matter that needs to be mastered by high school students as the preliminary condition of statistical material that is very much used in designing research and processing research data from various branches of science. According to the High School Mathematics teachers that the most difficult material for their students is the enumeration rule which is the subject matter. Difficulties about the material of enumeration rules are not only felt in Indonesia but also in developed countries. This can be seen in Pratt's (2000) study entitled "Making Sense of The Total of Two Dice", and Abrahamson \& Cendak (2006) study entitled The Odds of Understanding The Law of Large Number. Pratt's research tells the student's dexterity of determining the many ways a number emerges from the number of eyes the two dice are thrown, while Abrahamson's study tells students' difficulties understanding the concept of combination.

Curriculum 2013 requires teacher to be able to use learning resources provided, to be able to develop the media or other learning resources that may support the learning activity, and to be able to develop learning process to facilitate students in the learning process in line with the future important competence needed by the students (Dewey, 2013; Gonwa \& Wadei, 2013; Goodson, 2013; Pinar, 2013; Tyler, 2013). The Necessary relevance between mathematical concepts that have been studied children with the reality of their daily lives or in the other fields. To that end, the relevance of mathematics learning should take advantage of the child when learning mathematics (Ball \& Bass, 2000; Boaler, 2002; Cucker \& Smale, 2002; Duval, 2006; Freeman et al., 2014).

Rusman (2012), stated that one of the competence that a teacher must possess is to master the foundation of the education which discusses about teacher's ability to select, to develop and to use the learning resources. In addition, Regulation of national education minister (Permendiknas) number 71 in 2013 requires a teacher at education unit to be able to develop learning devices which contains Lesson Plan where one of the elements is learning resources. Student Assignment (LKPD) is one of the learning resources that can be developed by the teacher. Learning devices based Realistic Mathematics Education (RME) which consists of Lesson Plan (RPP) and Student Assignment (LKPD) considered as able to motivate students to understand the meaning of learning material by relating it with their daily life context.

The purpose is to enrich the students with knowledge and skill to be implemented in solving different problems. Realistic Mathematics Education (RME) is a learning theory developed in Holland by Haans Freudhental since 1971, learning devices based realistic mathematics is a device which refers to assumption that mathematics has to be related with reality and mathematics is a human activity (Korthagen, Kessels, Koster, Lagerwerf, \& Wubbels, 2001; Kwon, 2002; Van den Heuvel-Panhuizen \& Drijvers, 2014).

Realistic mathematics education is to use the problem that can be imagine or understood by the students to build their knowledge such as the use of daily life problems or to relate them with the learned and comprehended concepts previously by the students. Probability learning materials is a material that is really close to the daily life of the student, particularly toward the graduate of high schools. The probability theory is used to determine the probability of the graduates to be accepted at the public higher education through comparing data in the previous years between the number of the accepted students and the total number of the registrant. The knowledge of probability is really useful for the students to develop their knowledge prior to enter the higher education level based on their interest. It is due to the probability theory is not merely to be implemented in mathematics, but this theory may as well to be implemented in the other 
disciplines such as geography, economics, physics, techniques, and the like.

RME approach is based on Freudenthal's interpretation of mathematics as a human activity (Streefland, 1991; Van Den Heuvel-Panhuizen, 2003; Widjaja \& Heck, 2003). From this perspective, students should learn mathematics by mathematizing subject matter from realistic situations and by mathematizing their own mathematical activity (Rasmussen \& King, 2000). RME approach is contrary to conventional approach that mostly used by the teachers in Indonesia to teach mathematics.

We employed RME approach in this research because in line with the idea of how mathematics has to be taught in RME. Process of learning mathematics in RME can be described as a phenomenon of an iceberg below (Barnes, 2004, 2005; Fauzan, Slettenhaar, \& Plomp, 2002b; Kaiser \& Sriraman, 2006).

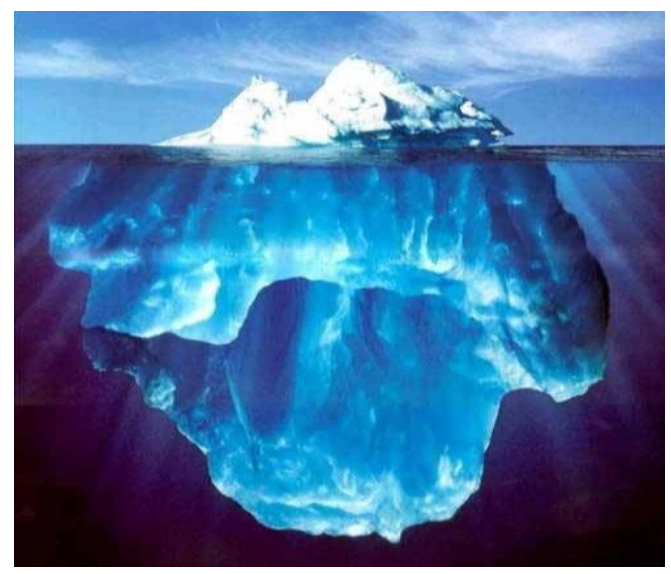

Photo: Frans Moerlands

Figure 1. RME as a phenomenon of an iceberg

A very strong foundation is needed to support the top of the iceberg to appear on sea surface. In relation to this phenomenon, formal and abstract mathematical concepts are situated on the top of the iceberg. Mathematics educators or researchers need to provide a strong foundation and 'a best trajectory' for students to reach the top of the iceberg. To do so, at the beginning of the lesson, students are provided with contextual problems that can be solved using their informal knowledge. The contextual problems will also facilitate students to use their own symbols or their own strategy. This process is called horizontal mathematization. After experiencing similar processes and empowering by simplification and formalization, students will use more formal language or strategies in solving contextual problems. The journey, that will bring students to re-invent a formal mathematical, is called vertical mathematization (Michelsen, 2005).

Conventional approach refers to the way of teaching in which teacher mostly starts a mathematics lesson by explaining an algorithm or a formula. Then, teacher gives example(s) to show how the algoritm or formula works, followed by students' activity of solving mathematical problems that are similar to the example(s) given by the teacher (Fauzan, 2002; Fauzan et al., 2002b; Fauzan, Slettenhaar, \& Plomp, 2002a). By using conventional approach, the teachers teach ready made mathematics, that is the mathematics of mathematicians (Cobb, Stephan, McClain, \& Gravemeijer, 2010; Drijvers, Doorman, Boon, Reed, \& Gravemeijer, 2010; Drijvers et al., 2010; Sembiring, 2010). Students tend to perform unexpected behaviours during teaching and learning process. The students are obstructing their peers, lots out of class permission, drawing or just doing nothing on their desk. Thus, the low attention display by the students during mathematics and learning process along with the difficulty they face in comprehending the learning material are obstacles experienced by the teacher to achieve the learning goal.

Meanwhile, RME approach facilitates students to build conceptual understanding using their informal knowledge. If the conventional approach tends to put an algorithm as a strarting point, then RME approach puts it as an end of the instruction (Hadi, 2013; Hough \& Gough, 2007). To understand an algorithm, students will works on contextual problems that gradually will give them experiences to find the algorithm by themselves under the guidance of the teacher (Barnes, 2005; Clements \& Sarama, 
2004; Cobb et al., 2010; Kaiser \& Sriraman, 2006; Leder, Pehkonen, \& Törner, 2006; Webb, Van der Kooij, \& Geist, 2011; Widjaja $\&$ Heck, 2003) at Figure 2.

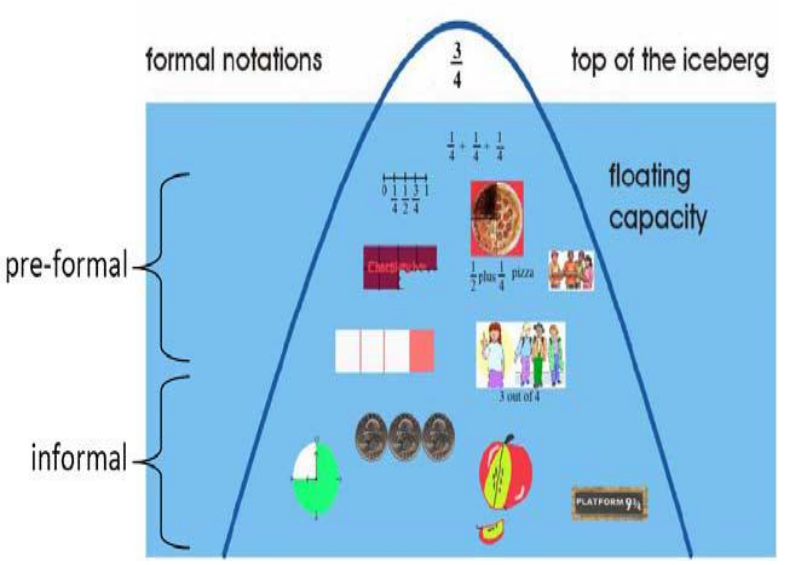

Figure 2. Building conceptual understanding by solving contextual problems using informal knowledge

In learning mathematics using RME approach, students will experience how to solve a contextual problem using their informal knowledge. This process is called horizontal mathematization. At the beginning, students will solve the problems informally using their own ways, their own words, or their own symbols. After experiencing a similar process (trough simplification and formalization), they will use more formal ways or symbols that will lead them to reinvent an algorithm or a formal mathematical concept. This kind of process is called vertical mathematization (Devrim \& Uyangor, 2006). In experiencing horizontal and vertical mathematization, the students will use multiple representations in form of real world object, model, pictures, graph, tables, or symbols.

In comparing the effect of RME and conventional approach on students' mathematical representation ability, we also involved gender and learning styles (auditory, visual, and kinesthetic) of the students as variables. There were some reasons behind this idea. Firstly, most teachers in Indonesia rarely consider gender and learning styles in choosing an approach in teaching mathematics. Secondly, male or female students or students with a certain learning style might have different preferences in using mathematical representations (Caligaris, Rodríguez, \& Laugero, 2015; Hickendorff, 2013). Thirdly, RME approach accommodates gender and learning styles differences when students get involve in doing mathematics activities (Fauzan et al., 2002a). The differences are also accommodated by characteristics of RME such as students' free productions, students' contributions, and interactivity.

\section{METHOD}

This research is a research and development. The 4-D model consists of four development stages, namely define, design, develop and disseminate. This research development was only in 3 steps. Define is to determine and define the requirements need to develop learning devices. This stage is also to analyze the goal and limitation of the developed learning material. Next, design step is to pay attention on three product characteristics, namely: content, interface and support. At the develop step, formative evaluation is take place. It consists of prototyping stage (self evaluation, expert reviews, one-to-one evaluation and small group).

Ardhana (2002) mentioned that "Research and Development (R\&D) is a development and validation processes of education product". On this research, the resulting product is mathematics learning devices based on Realistic Mathematics Education (RME). The resulted learning devices are in the form of Lesson Plan (RPP) and Student Assignment (LKPD.) The testing subject in this research is students of class $\mathrm{X}$ MAN Koto Baru Solok and mathematics teachers of MAN Koto Baru Solok. The instrument used in this research is Validation Sheet of Mathematics Learning Devices and Practicality Test Sheet.

This study included a type of literature study. With literature study is a way used to collect data and sources related to the topics raised in a study. The data sources containing: a mathematical problem solving ability, 
approach Realistic Mathematic Education $(R M E)$. The sources are obtained from journals, books, articles, research reports and internet sites.

In general, this developed model can be seen in the following chart I:

The mathematics learning devices chart based on Realistic Mathematics Education (RME).

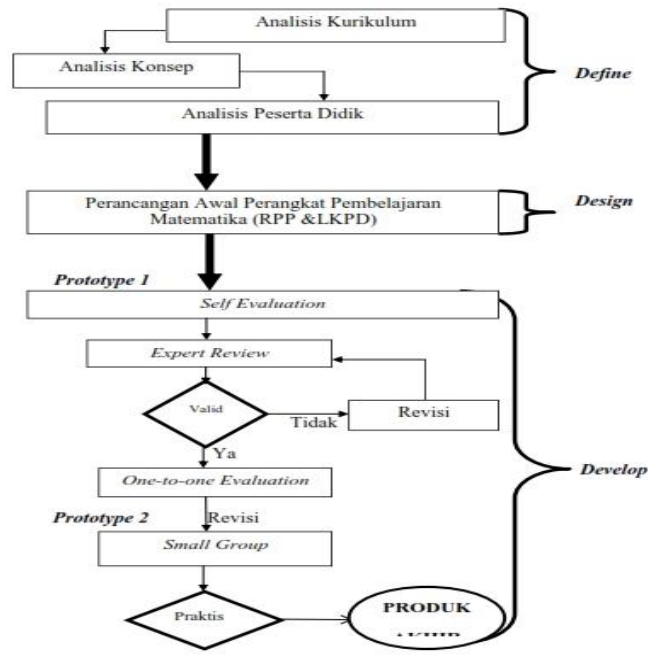

\section{RESULT AND DISCUSSION}

The result of this research is about activity in developing mathematics learning devices in the form of Lesson Plan (RPP) and Student Assignment (LKPD) which involves the result of define, design and develop.

On the define stage, curriculum analysis which is in line with curriculum 2013 is take place, next the analysis of the students' characteristics, and the last one is the define stage to analyze the concept in the form of concepts identification in teaching which arranged in detail and systematic.

The design stage is to design the mathematics learning devices in the form of Lesson Plan (RPP) and Student Assignment (LKPD) that will be developed and assessment instrument that will be implemented. The final result of this design stage is initial design of Lesson Plan (RPP) and Student Assignment (LKPD) that will be developed and the assessment instrument of learning devices quality. Below is the specification of research product on the design stage:

\section{Lesson Plan (RPP) Initial Design}

Lesson plan (RPP) is design based on writing steps of the Lesson Plan that has been explained on the previous chapter. Below is the initial stage of the Lesson Plan (RPP) in the form of writing order which consists of:

a. The identity of the Lesson Plan (RPP)

b. Basic Competence

c. Basic Competence and Competence Achievement Indicator

d. The purpose of the Learning

e. Learning Material

f. Learning Method

g. Media/ Devices/ Resources of Learning

h. Learning activity

i. Learning Result Assessment

Moreover, the developed Lesson Plan (RPP) also design based on the appropriateness of the aspect in relation with the characteristics of mathematics learning based on Realistic Mathematics Education (RME), so that the designed learning activity may facilitate students in relating the materials that they learned with the daily life problems in order to have a more meaningful learning activity.

\section{The initial design of Student} Assignment (LKPD)

a. The performance of initial cover of LKPD

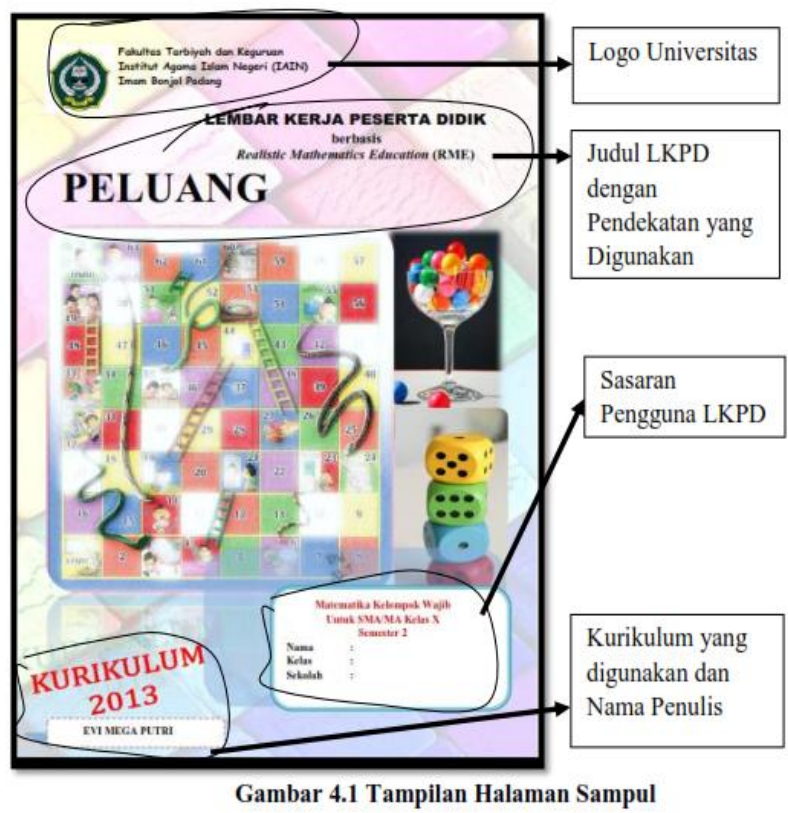


b. The performance of opening page of each activity on LKPD

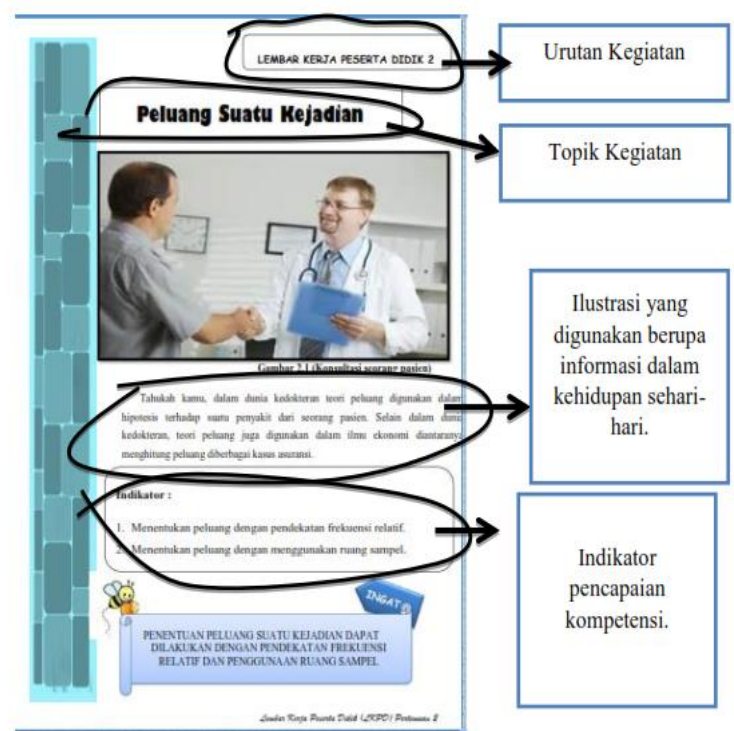

Gambar 4.6 Tampilan Halaman Pembuka untuk Setiap kegiatan

c. The performance of learning activity on LKPD based on RME

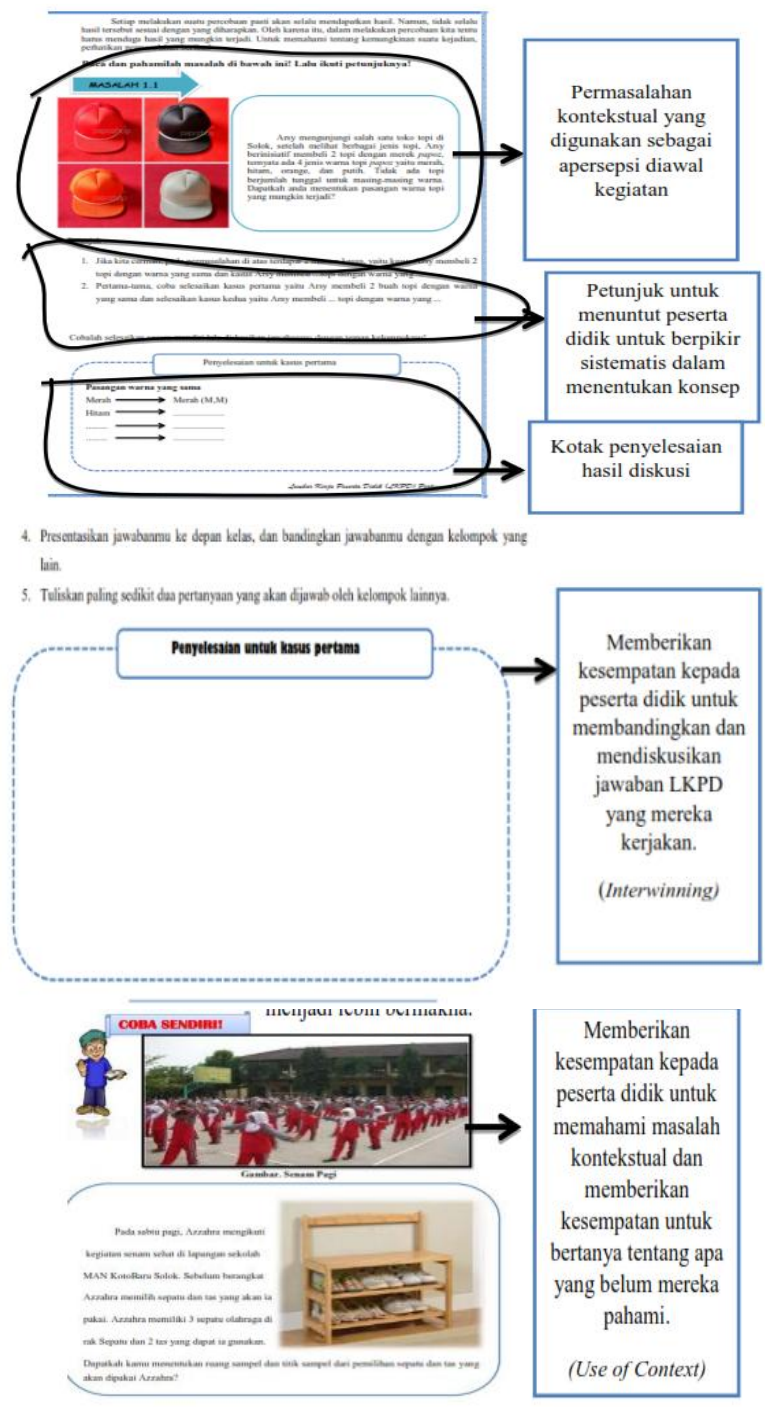

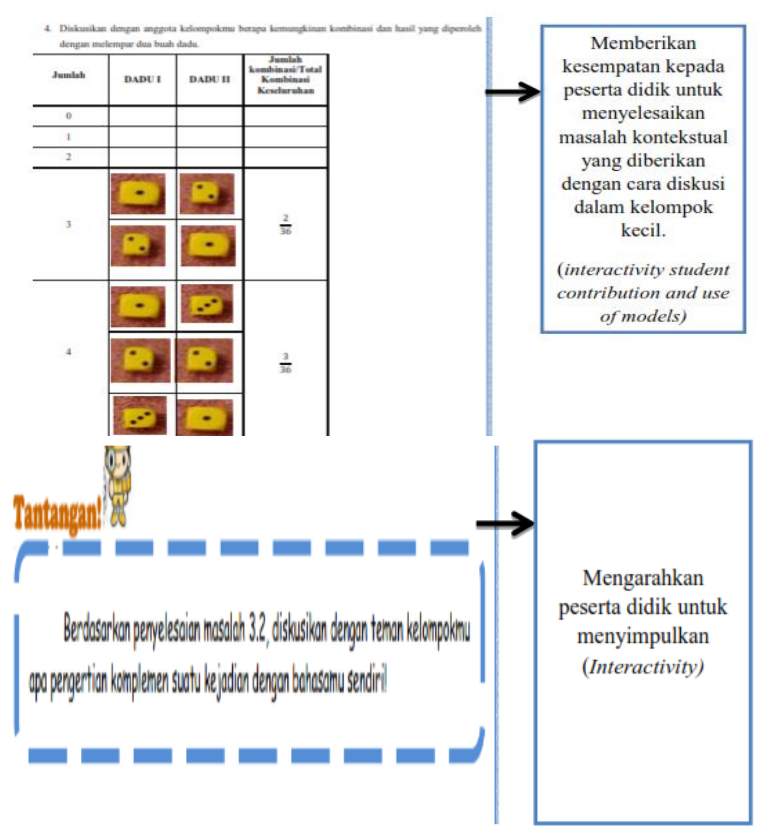
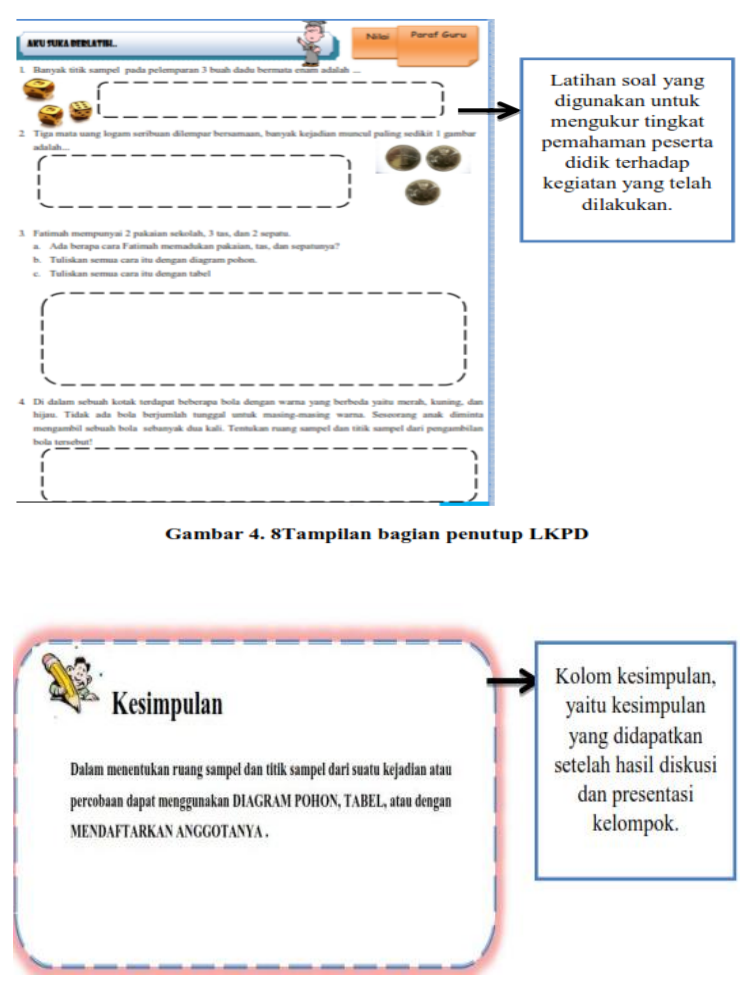

The designed mathematics learning devices is validated and practiced by the expert of mathematics education which consists of five validators.

The result of mathematics learning devices validation can be seen on the following table 1: 
Table 1. Assessment Detail on Lesson Plan (RPP)

\begin{tabular}{|c|c|c|}
\hline Aspect of Assessment & Average & Criteria \\
\hline $\begin{array}{l}\text { The Identity of Lesson } \\
\text { Plan (RPP) }\end{array}$ & 3.73 & $\begin{array}{l}\text { Very } \\
\text { Valid }\end{array}$ \\
\hline Time Allocation & 3.2 & Valid \\
\hline The Formulation & & \\
\hline $\begin{array}{l}\text { Material Achievement } \\
\text { Indicator and the Purpose } \\
\text { of the Learning }\end{array}$ & 3.45 & Valid \\
\hline Learning Material & 3.16 & Valid \\
\hline $\begin{array}{l}\text { Learning Method and } \\
\text { Approach based on RME }\end{array}$ & 3.24 & Valid \\
\hline $\begin{array}{l}\text { Media/Learning } \\
\text { Resources }\end{array}$ & 3 & Valid \\
\hline $\begin{array}{l}\text { Learning activity based on } \\
\text { Curriculum } 2013\end{array}$ & 3 & Valid \\
\hline $\begin{array}{l}\text { The Assessment of } \\
\text { Learning Result }\end{array}$ & 3.23 & Valid \\
\hline
\end{tabular}

Table 2. The Assessment Detail of Student Assignment (LKPD)

\begin{tabular}{lcl}
\hline \multicolumn{1}{c}{$\begin{array}{c}\text { Aspect of the } \\
\text { Assessment }\end{array}$} & $\begin{array}{c}\text { Average } \\
\text { Score }\end{array}$ & Criteria \\
\hline Content feasibility & 3.34 & Valid \\
Presentation feasibility & 3.56 & Very Valid \\
Language feasibility & 3.28 & Valid \\
Graphics feasibility & 3.75 & Very Valid \\
\hline
\end{tabular}

The practicality is obtained through the questionnaire data of both teacher and student and supported by the result of observation, the implementation of learning and interview toward teacher and students. Below is the description of research result of testing held at MAN Koto Baru Solok.

Table 3. The Practicality Assessment on Lesson Plan (RPP) by Teacher

\begin{tabular}{|c|c|c|}
\hline $\begin{array}{l}\text { Aspect of the } \\
\text { Assessment }\end{array}$ & $\begin{array}{l}\text { Practicality } \\
\text { Score }\end{array}$ & Criteria \\
\hline $\begin{array}{l}\text { The component } \\
\text { completeness and the } \\
\text { presentation or } \\
\text { performance of }\end{array}$ & 3.1 & Practical \\
\hline $\begin{array}{l}\text { Student Assignment } \\
\text { LKPD }\end{array}$ & & \\
\hline $\begin{array}{l}\text { The ease in using } \\
\text { LKPD }\end{array}$ & 3.3 & Practical \\
\hline $\begin{array}{l}\text { The appropriateness } \\
\text { between the devices } \\
\text { and the time }\end{array}$ & 3 & Practical \\
\hline
\end{tabular}

Table 4. Practicality Assessment on LKPD by students

\begin{tabular}{lcc}
\hline $\begin{array}{l}\text { Aspect of the } \\
\text { Assessment }\end{array}$ & $\begin{array}{c}\text { Practicality } \\
\text { Score }\end{array}$ & Criteria \\
\hline $\begin{array}{l}\text { The appropriateness } \\
\text { of material based }\end{array}$ & 3.34 & Practical \\
$\begin{array}{l}\text { on RME } \\
\text { Language } \\
\text { feasibility }\end{array}$ & 3.30 & Practical \\
$\begin{array}{l}\text { Presentation } \\
\text { feasibility } \\
\begin{array}{l}\text { Graphics } \\
\text { feasibility }\end{array}\end{array}$ & 3.56 & $\begin{array}{c}\text { Very } \\
\text { Practical } \\
\text { Very }\end{array}$ \\
\hline
\end{tabular}

The table above shows that the developed Lesson Plan (RPP) and Student Assignment (LKPD) are valid and practical including the comments from both valildator and teacher.

The development is to do the formative evaluation which includes self evaluation and prototype stage (expert review, one-to-one evaluation, and small group).

\section{CONCLUSION AND RECOMMENDATION}

Based on the research result and the discussion, it can be concluded that: The development of mathematics learning device based on Realistic Mathematics Education (RME) on Probability learning materials for Senior High School (SMA/MA) class $X$ is valid in criteria of Lesson Plan with average 3.25 and is valid in criteria of Student Assignment (LKPD) with average 3.48.

Learning devices based on the developed Realistic Mathematics Education (RME) is practical in criteria. This practicality can be seen from the result of the questionnaire distributed toward the students and the teacher with the average score 3.50 for Lesson Plan (RPP) and 3.30 for Student Assignment (LKPD) and the interview result with both teacher and students.

Based on this research and development, below is some recommendations by the researcher: The testing on the learning devices based on Realistic Mathematics Education (RME) is just implemented toward one class and the 
testing material is on one material only. It is suggested that the future researcher would test it to the other class by using broader number of testing materials, so that it may minimized the disadvantage of Student Assignment (LKPD).

The testing of this learning devices based on Realistic Mathematics Education (RME) is held for three meetings only. It is suggested that future prospect researcher may test in a larger amount of meetings so that the data and conclusion obtained can be more accurate.

This research is limit up to develop stage. In order to get a better result, it is suggested that this research should also be tested on other school so that the research result can be developed forward to the disseminate stage.

\section{REFERENCES}

Abrahamson, D., \& Cendak, R. M. (2006). The odds of understanding the law of large numbers: A design for grounding intuitive probability in combinatorial analysis. In Proceedings of the Thirtieth Conference of the International Group for the Psychology of Mathematics Education (Vol. 2, pp. 1-8).

Ardhana, W. (2002). Konsep penelitian pengembangan dalam bidang pendidikan dan pembelajaran. Makalah Disampaikan Pada Lokakarya Nasional Angkatan II Metodologi Penelitian Pengembangan Bidang Pendidikan Dan Pembelajaran. Malang: Universitas Negeri Malang.

Ball, D. L., \& Bass, H. (2000). Interweaving content and pedagogy in teaching and learning to teach: Knowing and using mathematics. Multiple Perspectives on the Teaching and Learning of Mathematics, 83-104.

Barnes, H. (2004). Realistic mathematics education: Eliciting alternative mathematical conceptions of learners. African Journal of Research in Mathematics, Science and Technology Education, 8(1), 53-64.

Barnes, H. (2005). The theory of Realistic Mathematics Education as a theoretical framework for teaching low attainers in mathematics. Pythagoras, 2005(61), 42-57.

Boaler, J. (2002). Experiencing school mathematics: Traditional and reform approaches to teaching and their impact on student learning. Routledge.

Caligaris, M., Rodríguez, G., \& Laugero, L. (2015). Learning styles and visualization in numerical analysis. Procedia-Social and Behavioral Sciences, 174, 3696-3701.

Clements, D. H., \& Sarama, J. (2004). Learning trajectories in mathematics education. Mathematical Thinking and Learning, 6(2), 81-89.

Cobb, P., Stephan, M., McClain, K., \& Gravemeijer, K. (2010). Participating in classroom mathematical practices. In A journey in mathematics education research (pp. 117-163). Springer.

Council, N. R., \& Committee, M. L. S. (2001). Adding it up: Helping children learn mathematics. National Academies Press.

Cucker, F., \& Smale, S. (2002). On the mathematical foundations of learning. Bulletin of the American Mathematical Society, 39(1), 1-49.

Devrim, U., \& Uyangor, S. M. (2006). Attitudes of 7 th class students toward mathematics in realistic mathematics education. In International Mathematical Forum (Vol. 1, pp. 1951-1959).

Dewey, J. (2013). The school and society and the child and the curriculum. University of Chicago Press. 
Drijvers, P., Doorman, M., Boon, P., Reed, H., \& Gravemeijer, K. (2010). The teacher and the tool: instrumental orchestrations in the technology-rich mathematics classroom. Educational Studies in Mathematics, 75(2), 213234.

Duval, R. (2006). A cognitive analysis of problems of comprehension in a learning of mathematics. Educational Studies in Mathematics, 61(1-2), 103131.

Fauzan, A. (2002). Applying Realistic Mathematics Education (RME) in teaching geometry in Indonesian primary schools.

Fauzan, A., Slettenhaar, D., \& Plomp, T. (2002a). Teaching Mathematics in Indonesian Primary Schools Using Realistic Mathematics Education (RME)-Approach. In The Second International Conference on the teaching of mathematics at the undergraduate level (pp. 1-6).

Fauzan, A., Slettenhaar, D., \& Plomp, T. (2002b). Traditional mathematics education vs. realistic mathematics education: Hoping for changes. In Proceedings of the 3rd International Mathematics Education and Society Conference (pp. 1-4). Centre for Researh in Learning Mathematics Copenhagen, Denmark.

Freeman, S., Eddy, S. L., McDonough, M., Smith, M. K., Okoroafor, N., Jordt, H., \& Wenderoth, M. P. (2014). Active learning increases student performance in science, engineering, and mathematics. Proceedings of the National Academy of Sciences, 111(23), 8410-8415.

Gonwa, T. A., \& Wadei, H. M. (2013). Kidney disease in the setting of liver failure: core curriculum 2013. American Journal of Kidney Diseases, 62(6), 1198-1212.

Goodson, I. F. (2013). School subjects and curriculum change. Routledge.
Hadi, A. (2013). Pengaruh pembelajaran problem based learning (PBL) terhadap kemampuan berpikir kritis dan pemahaman konsep biologi siswa SMA Negeri di kota Malang. SKRIPSI Jurusan Biologi-Fakultas MIPA UM.

Hickendorff, M. (2013). The effects of presenting multidigit mathematics problems in a realistic context on sixth graders' problem solving. Cognition and Instruction, 31(3), 314-344.

Hough, S., \& Gough, S. (2007). Realistic Mathematics Education. Mathematics Teaching Incorporating Micromath, 203, 34-38.

Kaiser, G., \& Sriraman, B. (2006). A global survey of international perspectives on modelling in mathematics education. ZDM, 38(3), 302-310.

Korthagen, F. A., Kessels, J., Koster, B., Lagerwerf, B., \& Wubbels, T. (2001). Linking practice and theory: The pedagogy of realistic teacher education. Routledge.

Kwon, O. N. (2002). Conceptualizing the Realistic Mathematics Education Approach in the Teaching and Learning of Ordinary Differential Equations.

Leder, G. C., Pehkonen, E., \& Törner, G. (2006). Beliefs: A hidden variable in mathematics education? (Vol. 31). Springer Science \& Business Media.

Mathematics, N. C. of T. of. (2000). Principles and standards for school mathematics (Vol. 1). National Council of Teachers of.

Michelsen, C. (2005). Expanding the domain: Variables and functions in an interdisciplinary context between mathematics and physics. In Proceedings of the 1st International Symposium of Mathematics and its Connections to the Arts and Sciences (pp. 201-214). Citeseer.

Pinar, W. F. (2013). International handbook of curriculum research. Routledge. 
Pratt, D. (2000). Making sense of the total of two dice. Journal for Research in Mathematics Education, 602-625.

Rasmussen, C. L., \& King, K. D. (2000). Locating starting points in differential equations: A realistic mathematics education approach. International Journal of Mathematical Education in Science and Technology, 31(2), 161172.

Rusman, D., \& Pd, M. (2012). Model-Model Pembelajaran. Raja Grafindo, Jakarta.

Sembiring, R. K. (2010). Pendidikan Matematika Realistik Indonesia (PMRI): Perkembangan dan Tantangannya. Journal on Mathematics Education, 1(1), 11-16.

Streefland, L. (1991). Fractions in realistic mathematics education: A paradigm of developmental research (Vol. 8). Springer Science \& Business Media.

Tyler, R. W. (2013). Basic principles of curriculum and instruction. University of Chicago press.
Van Den Heuvel-Panhuizen, M. (2003). The didactical use of models in realistic mathematics education: An example from a longitudinal trajectory on percentage. Educational Studies in Mathematics, 54(1), 9-35.

Van den Heuvel-Panhuizen, M., \& Drijvers, P. (2014). Realistic mathematics education. In Encyclopedia of mathematics education (pp. 521-525). Springer.

Webb, D. C., Van der Kooij, H., \& Geist, M. R. (2011). Design research in the Netherlands: Introducing logarithms using realistic mathematics education. Journal of Mathematics Education at Teachers College, 2(1).

Widjaja, Y. B., \& Heck, A. (2003). How a realistic mathematics education approach and microcomputer-based laboratory worked in lessons on graphing at an Indonesian junior high school. Journal of Science and Mathematics Education in Southeast Asia, 26(2), 1-51. 